\title{
Civilians and Armed Conflict
}

Rosa Brooks

Georgetown University Law Center, rosa.brooks@law.georgetown.edu

This paper can be downloaded free of charge from:

https://scholarship.law.georgetown.edu/facpub/1258

http://ssrn.com/abstract=2308102

Rosa Brooks, Civilians and Armed Conflict, in THE UNITED NATIONS SECURITY COUNCIL IN THE AGE OF HUMAN RIGHTS, (Jared Genser \& Bruno Ugarte, eds., New York: Cambridge University Press (2014))

This open-access article is brought to you by the Georgetown Law Library. Posted with permission of the author. Follow this and additional works at: https://scholarship.law.georgetown.edu/facpub 


\title{
The United Nations Security Council in the Age of Human Rights
}

\author{
EDITED B Y \\ JARED GENSER \\ Perseus Strategies \\ BRUNO STAGNO UGARTE
}

Security Council Report 


\title{
Civilians and Armed Conflict
}

\author{
Rosa Brooks
}

\section{ORIGINS}

We tend to view concern with the protection of civilians as a relatively recent development within the Security Council: a product of the late twentieth-century genocides and ethnic cleansing campaigns in Rwanda and the Balkans. But although it is indeed true that the Council's first thematic resolution directly addressing "protection of civilians" was not passed until 1999 - and also true, unfortunately, that Security Council civilian protection efforts have yet to move beyond the sporadic and inconsistent - the Council has always concerned itself with civilian protection. Indeed, the history of the Security Council itself (as well as the history of the United Nations (UN) as a whole) is in many ways inextricably interwoven with concerns about the protection of civilians during armed conflicts.

The UN was a product of the most destructive war humanity has yet seen, and it is impossible to make sense of the UN except against this backdrop of carnage and devastation. During the Second World War, an estimated 50-60 million people were killed in the space of half a decade, and at least 20 million of those deaths were among the civilian population. As the realities of that terrible war recede further and further into the past, they have increasingly lost their power to shock; for those reaching adulthood today, World War II is as distant as the Franco-Prussian war or the American Civil War was to those who reached adulthood in the 1930 and '4os. For the diplomats who gathered to draft the UN Charter in San Francisco in April 1945, however, the war was no fading memory, but an ongoing reality.

The Nazi concentration camps at Auschwitz-Birkenau had been liberated by Allied forces just months before the San Francisco conference began. On the Pacific front, the March 9, 1945 firebombing of Tokyo had left an estimated 100,000 dead - most of them civilians - in a single aerial raid.' And new horrors were revealed each day, even as the conference delegates in San Francisco busied themselves with the making of formal speeches and the endless legalistic revision of carefully worded drafts.

1 Tony Long, March 9, 1945: Burning the Heart Out of the Enemy, Wired MaGazine, Mar. 9, 2011. 
Dachau was liberated two days after the San Francisco conference began. Adolf Hitler's suicide came a few days later, and Germany's surrender a week after that. And this did not yet mark the end of the Second World War's slaughter. In the months following that first conference in San Francisco, a devastated Europe struggled to assess the carnage and begin the painful task of rebuilding. Meanwhile, the war in the Pacific raged on. In August, the United States dropped atomic bombs on the Japanese cities of Hiroshima and Nagasaki, killing another 135,000 people, mostly civilians. Japan signed formal documents of surrender on September 2, 1945, and on October 24, less than two months after the war's end, the UN Charter entered into force.

Seven decades on from that increasingly unimaginable time, legal commentators refer frequently to Chapter I of the UN Charter, which declares that the UN's purpose is "to maintain international peace and security." But we refer less often to the Charter's preamble, with its poignant opening lines: "We the peoples of the United Nations" are determined "to save succeeding generations from the scourge of war, which twice in our lifetime has brought untold sorrow to mankind." Today, we are apt to view this as mere rhetoric, hortatory language without legal effect or words that can be safely ignored by procedurally focused technocrats. But if we wish to contextualize the Security Council's engagement with civilian protection, we would do well to take these words seriously. In 1945, the "untold sorrow" of war could remain untold, for the simple reason that most of the men and women who drafted the UN Charter had experienced those sorrows firsthand, as had the leaders and populations of the states that employed them.

Given the preoccupation with state sovereignty that continues to complicate today's civilian protection efforts, we should also note that the Charter's preamble is offered not in the name of nations, states, or leaders, but as a commitment by and to the "peoples" of the UN. Like all institutions created by human beings, the UN was compromised by the cold realities of politics from its earliest moments. But though it has never fully lived up to the hopes once attached to it, it is nevertheless worth recalling its founding vision: a world that valued human beings above all, and a world in which those artificial political constructs we refer to as "states" were at the service of the people who populated them, rather than the other way around.

In the UN Charter the "peoples of the United Nations" further reaffirmed their "faith in fundamental human rights, in the dignity and worth of the human person, in the equal rights of men and women and of nations large and small." They pledged "to establish conditions under which justice and respect for the obligations arising from treaties and other sources of international law can be maintained, and ... promote social progress and better standards of life in larger freedom ... to practice tolerance and live together in peace with one another as good neighbors, and to unite our strength to maintain international peace and security, and to ensure, by the acceptance of principles and the institution of methods, that armed force shall not be used, save in the common interest, and to employ international machinery for the 
promotion of the economic and social advancement of all peoples..." These were radical words in 1945, and they remain no less so today.

Of course, this utopian spirit proved unsustainable. Inevitably, the UN shifted from a visionary organization born of world-shattering crisis to a clumsy bureaucracy crippled by Cold War politics. Voting rules for the Security Council give veto power to any of its five permanent members, and for decades, ideological divisions reduced Security Council activities to a focus on lowest-common-denominator issues. This unedifying story has been well told elsewhere, so it need not be detailed here.

\section{SECURITY COUNCIL ENGAGEMENT WITH CIVILIAN PROTECTION ISSUES IN THE COLD WAR ERA}

Even in the midst of its Cold War calcification, the Security Council showed an interest in the protection of civilians, both in the context of armed conflicts and also, occasionally, in the context of state repression. Consider, for instance, Security Council Resolution 93 (195i) "relating to the General Armistice Agreements between Israel and the neighboring Arab States" following the 1948 Arab-Israeli War. ${ }^{2}$ In what was to become one of scores of resolutions on Arab-Israeli relations (most, unfortunately, ineffectual), the Council called on Israel and Syria to abide by the terms of the 1949 General Armistice Agreement, noting specifically that Israel had violated the Armistice agreement in its April 5 air raids, and reminding both parties of their Armistice pledge to endow the chairman of the UN's Mixed Armistice Commission with the authority to make "all necessary arrangements for the restoration and protection of civilian life" in the demilitarized zone.

In 1960, the Council addressed a non-conflict-related civilian protection issue, responding to a complaint made by twenty-nine member states regarding "the large scale killing of unarmed and peaceful demonstrators against racial discrimination" in South Africa. In Resolution 134 (1960), the Council noted that South Africa's apartheid policies had led to "international friction and if continued might endanger international peace and security," "deplored" the "loss of life of so many Africans," and called upon South Africa to end apartheid. ${ }^{3}$ In 1961, the Council expressed a more oblique concern for civilians in a resolution responding to the murder of Congolese leader Patrice Lumumba and two colleagues: in Resolution 161 (1961), the Council expressed itself "deeply concerned with the grave repercussions of these crimes and the danger of widespread civil war and bloodshed in the Congo." It also "noted with deep regret and concern the systematic violations of human rights and fundamental freedoms and the general absence of the rule of law

$=$ UN Security Council Resolution 93, S/RES/93, May 18, 1951. Adopted 10-1, with the Soviet Union abstaining.

3. UN Security Council Resolution 134, S/RES/134, Apr. 1, 1960. Adopted 9-0-2, with France and the United Kingdom abstaining. 
in Congo, and urged that "Congolese armed units be ... brought under discipline and control."4

In 1967 , the Council again referenced the importance of civilian protection during armed conflicts, this time in a resolution focusing on the aftermath of Israel's Six Day War against Egypt, Syria, and Jordan: "Considering the urgent need to spare the civil populations ... in the area of conflict," Resolution 237 (1967) reminded parties to the conflict of their obligations under the Geneva Conventions and urging "scrupulous respect of the humanitarian principles governing ... the protection of civilian persons in time of war." In 1968, the Council likewise condemned Portugal for attacks on a Zambian village "resulting in the loss of civilian life and property." 6

A few years later, following the 1971 Indo-Pakistani War, which forced nearly 10 million civilians to flee their homes and left as many as 3 million people dead, 7 the Council called on parties to the conflict to "take all measures necessary for the preservance of human life and ... apply in full" provisions of the Geneva Conventions "as regards the protection of the ... civilian population." ${ }^{8}$ In 1977, the Council again condemned South Africa's apartheid government for "the wanton killings of the African people, including schoolchildren," and its "indiscriminate violence" against peaceful protesters." In 1979, the Council also condemned South Africa's "premeditated, persistent and sustained armed invasions" of Angola. Declaring itself "grieved at the tragic and mounting loss in human life, including that of civilians," it requested that the Secretary-General "obtain available information from the People's Republic of Angola on human casualties ... resulting from repeated acts of aggression" by South Africa. ${ }^{10}$

Throughout the 1970s, the Council remained concerned by Portuguese actions in its African colonies. Its focus on South African government abuses and conflicts and on conflicts between Israel and its neighbors also continued into the 1980s. During the 1980 s, the Council became similarly concerned with "heavy losses of civilian life" during the 1980-1988 Iran-Iraq War, calling in Resolution 540 (1983) for the "immediate cessation of all military operations against civilian targets." In Resolution 582 (1986), also focused on the Iran-Iraq War, it decried "the bombing

4 UN Security Council Resolution 161, S/RES/161, Feb. 21, 1961. Adopted 9-0-2, with France and the Soviet Union abstaining.

5 UN Security Council Resolution 237, S/RES/237, Jun. 14, 1967. Adopted unanimously.

6 UN Security Council Resolution 268, S/RES/268, Jul. 28, 1969. Adopted 11-0-4, with France, Spain, the United Kingdom, and the United States abstaining.

7 Bruce O. Riedel, Deadly Embrace: Pakistan, America and the Future of Grobal Jihad (Brookings Institution Press, 2012).

8. UN Security Council Resolution 307, S/RES/307, Dec. 21, 1971. Adopted unanimously.

9 UN Security Council Resolution 47, S/RES/417, Oct. 31, 1977. Adopted unanimously.

10 UN Security Council Resolution 447, S/RES/447, Mar. 28, 1979. Adopted 12-0-3, with France, the United Kingdom, and the United States abstaining.

11 UN Security Council Resolution 540, S/RES $/ 54^{\circ}$, Oct. 31, 1983. Adopted 12-0-3, with Malta, Nicaragua, and Pakistan abstaining. 
of purely civilian population centers ... [and] violation of international humanitarian law and other laws of armed conflict."'12

This is not an exhaustive list of Council resolutions addressing civilian protection issues prior to the end of the Cold War. It is intended, rather, as illustrative. Contrary to popular belief, the Council's concern with issues of civilian protection has manifested itself many times over the decades, although it was not until the late 1990 s that the Council began to elaborate on the nature of civilian protection norms. Until the Cold War's end, the Council was often eclectic in its terminology, not always citing civilian protection concerns in so many words. Instead, references to civilian protection were often implied rather than explicit, with the Council sometimes calling on parties to conflicts to abide by the Geneva Conventions, and at other times simply lamenting what it variously referred to as "bloodshed," 33 "loss of life,"14 "wanton killings," "deaths,"15 "massive violence and killings"' and so on, both in the context of armed conflicts and in the context of state repression.

The Council was hardly consistent in its emphasis on civilian protection, however. While multiple Security Council resolutions relating to Israeli-Arab conflicts continued to emphasize civilian protection concerns during the Cold War era, considerations of realpolitik led to utter silence from the Council on civilian deaths in most other settings. Unsurprisingly, given the veto power held by its five permanent members, the Council had nothing to say about civilian casualties caused by the activities of China, France, the United States, the United Kingdom, or the Soviet Union. Civilian deaths in the US war in Vietnam went unmentioned, as did civilian deaths caused by the 1970 covert US bombing of Cambodia. The 1979 Soviet invasion of Afghanistan also caused massive civilian casualties, but was greeted with similar silence by the Security Council.

The Council's primary focus on international armed conflicts and other threats to international peace and security was yet another reason for its inaction in the face of large-scale killings of civilians. Today, we would surely consider Joseph Stalin's purges or the death toll of the Chinese Cultural Revolution as civilian protection issues, but neither received any acknowledgment from the Security Council. For the most part, internal armed conflicts, genocides, crimes against humanity, and other atrocities were ignored by the Security Council even when no permanent members were directly concerned. Thus, although intense international pressure led the Council to repeatedly condemn violent repression and killings by the apartheid government of South Africa, the Khmer Rouge genocide in Cambodia was ignored

12 UN Security Council Resolution 582, S/RES/582, Feb. 24, 1986. Adopted unanimously.

i3 S/RES $/ 161$.

14 UN Security Council Resolution 419, S/RES/419, Nov. 24, 1977. Adopted without vote.

15 UN Security Council Resolution 273, S/RES/273, Dec. 9, 1969. Adopted 13-0-2, with Spain and the United States abstaining.

${ }^{16} \mathrm{~S} / \mathrm{RES} / 417$. 
entirely, as was ethnic slaughter in Uganda, Biafra, Burundi, Laos, East Timor, and Sudan - none merited even a single Council resolution during the Cold War period.

\section{THE END OF THE COLD WAR}

The end of the Cold War and the collapse of the Soviet Union broke many of the logjams blocking effective Security Council action. As Jared Genser and Bruno Stagno Ugarte note in Chapter 1, the post-Cold War period saw a rapid increase in Security Council activity on a wide variety of fronts:

Whereas [the Security Council] adopted 644 resolutions in the almost 44 years preceding the fall of the Berlin Wall, it ... adopted 1,441 resolutions in the 23 subsequent years ... From nine active peacekeeping missions in 1989 with a total of 11,000 troops, there were 14 active missions deploying 111,826 personnel, including 92,936 troops, by December 31, 2012, not including other important and more recent field presences such as political missions and peacebuilding offices. Or to put it otherwise, whereas 18 peacekeeping missions had been authorized since the founding of the United Nations to 1989 , 49 have been established since 1990. Moreover, the Council has authorized other unprecedented mandates operating under Chapter VII, such as international criminal tribunals, special courts and financial compensation or weapons inspection commissions.

In keeping with this generally higher level of activity, the Security Council's focus on civilian protection issues also increased with the Cold War's end. The August 1990 Iraqi invasion of Kuwait was the Council's first test, and at first blush, the results were impressive. The Council instantly condemned the invasion, demanding that "Iraq withdraw immediately and unconditionally all its forces." 77 This was followed by resolutions condemning the violation of Kuwaiti sovereignty and the "loss of human life ${ }^{n}$ caused by the invasion, and authorizing, in rapid succession, economic sanctions against Iraq and a naval blockade. In Resolution 670 (1990) the Council condemned "the treatment by Iraq̣i forces of Kuwaiti nationals," and noted that as a party to the Fourth Geneva Convention on the Protection of Civilians, "Iraq is bound to comply fully with all its terms and in particular is liable under the Convention in respect of the grave breaches committed by it, as are individuals who commit or order the commission of grave breaches." ${ }^{\prime \prime} 8$

When Iraq continued to ignore the demands of the international community, the Council, in Resolution 678 (1990), acted under its Chapter VII authority and authorized the use of "all necessary means" to restore the status quo if Iraq failed

17 UN Security Council Resolution 660, S/RES/660, Aug. 2, 1990. Adopted 14-0-0, with Yemen not participating.

18 UN Security Council Resolution 670, S/RES/670, Sept. 25, 1990. Adopted 14-1-0, with Cuba voting against. 
to withdraw its troops from Kuwait by January $15,1991 .^{19}$ Iraq failed to meet this deadline, and on January 17, 1991, an international coalition led by the United States took military action to force an Iraqi withdrawal from Kuwait.

During this period, the relative international harmony that characterized Security Council action against Iraq led many to believe that a new era was dawning. In September 1990, U.S. President George H.W. Bush spoke to a joint session of Congress:

I've just returned from a very productive meeting with Soviet President Gorbachev ... In Helsinki, our joint statement affirmed to the world our shared resolve to counter Iraq's threat to peace ... Clearly, no longer can a dictator count on East-West confrontation to stymie concerted United Nations action against aggression. Out of these troubled times ... a new world order - can emerge: a new era - freer from the threat of terror, stronger in the pursuit of justice, and more secure in the quest for peace ... A hundred generations have searched for this elusive path to peace, while a thousand wars raged across the span of human endeavor. Today that new world is struggling to be born ... A world where the rule of law supplants the rule of the jungle. A world in which nations recognize the shared responsibility for freedom and justice. A world where the strong respect the rights of the weak. ${ }^{20}$

In March 1991, with the brief Gulf War successfully concluded, Bush was still more sanguine:

[T]his I promise you: for all that Saddam has done to his own people, to the Kuwaitis, and to the entire world, Saddam and those around him are accountable. All of us grieve for the victims of war, for the people of Kuwait and the suffering that scars the soul of that proud nation ... for all the innocents caught up in this conflict....

Twice this century, out of the horrors of war hope emerged for enduring peace. Twice before, those hopes proved to be a distant dream, beyond the grasp of man. Until now, the world we've known has been a world divided - a world of barbed wire and concrete block, conflict and cold war. Now ... there is the very real prospect of a new world order .... A world where the United Nations, freed from Cold War stalemate, is poised to fulfill the historic vision of its founders. ${ }^{21}$

On the surface, the "new world order" was off to a good start. The US-led Gulf War Coalition left Saddam Hussein's government intact, but the Security Council remained attentive to conditions in Iraq, including civilian protection issues. On

19 UN Security Council Resolution 661, S/RES/661, Aug. 6, 1990, adopted 13-0-2, with Cuba and Yemen abstaining; UN Security Council Resolution 678, S/RES/678, Nov. 29, 1990, adopted 12-2-1, with Cuba and Yemen voting against and China abstaining.

20. George H.W. Bush, Address before a Joint Session of the Congress on the Persian Gulf Crisis and the Federal Budget Deficit, Sept. 11, 1990.

21 George H.W. Bush, Address before a Joint Session of Congress on the Cessation of the Persian Gulf Conflict, Mar. 6, 1991. 
April 5, 1991, for instance, the Council focused on Saddam Hussein's ruthless suppression of Kurdish and Shi'a rebellions within Iraq, condemning "the repression of the Iraqi civilian population in many parts of Iraq, including most recently in Kurdish-populated areas, the consequences of which threaten international peace and security in the region." 22 In response, the United States and other Coalition allies launched Operation Provide Comfort, designed to provide humanitarian assistance to Iraq's Kurdish population and prevent additional violence toward Iraqi Kurds by Saddam Hussein's government.

In January 1992, the Security Council met - for the first time in its history - at the heads-of-state level to reflect on its changing role. A post-summit statement by the UK Prime Minister (acting as Security Council President) observed that Council members agreed "that there are new favorable international circumstances under which the Security Council has begun to fulfill more effectively its primary responsibility for the maintenance of international peace and security... The ending of the Cold War has raised hopes for a safer, more equitable and more humane world ...."

Noting that members of the Council remained "concerned by the humanitarian situation of the innocent civilian population of Iraq," the Council President's statement also acknowledged the need for an increased Security Council focus on internal armed conflicts: "the absence of war and military conflicts among states does not in itself ensure international peace and security. The non-military sources of instability in the economic, social, humanitarian and ecological fields have become threats to peace and security. The United Nations membership as a whole, working through the appropriate bodies, needs to give the highest priority to the solution of these matters. ${ }^{23}$

It was a timely statement, for even as triumphant proclamations of the "new world order" continued, the Security Council had begun to wrestle with two crises that would prove decisive to its future civilian protection work. In Central Europe, Yugoslavia was coming apart at the seams. Meanwhile, in the Horn of Africa, famine and civil strife were tearing apart the Somali state.

\section{THE CONFLICTS OF THE 199OS}

In December 1990, with the world's attention focused on Iraq, voters in the Yugoslav Republic of Slovenia passed a referendum opting for independence from the Socialist Federalist Republic of Yugoslavia. In June 1991, both Slovenia and the Republic of Croatia declared themselves to be independent states. These declarations of independence were met by force from the Serb-dominated Yugoslav National Army, and the violent breakup of Yugoslavia was underway. The republics of Macedonia and Bosnia-Herzegovina soon declared their own independence, and

22 UN Security Council Resolution 688, S/RES/688, Apr. 4, 1991. Adopted 10-3-2, with Cuba, Yemen, and Zimbabwe voting against, and China and India abstaining.

${ }_{23}$ UN Security Council Resolution 688, 
by the spring of 1992, the region was engulfed in an all-out war of unparalleled viciousness. With the Former Yugoslavia fractured along ethnic lines, the targeting of civilians became common as different factions sought to drive rival ethnic groups from what they saw as "their" territory.

Despite the much-vaunted "new world order," the Security Council was slow with a meaningful response. With little understanding of the complex ethnic and political dynamics at play - and leftover Cold War client relationships still carrying weight for some of the Council's permanent members - the Council was able to agree that the violence was deplorable, but unable to agree on which side was to blame or on decisive action to halt the spreading conflict. As a first step, the Council simply imposed an arms embargo on the whole of the Former Yugoslavia (thus, in many ways, freezing into place power imbalances between Serbian forces and others).

In February 1992, the Council grudgingly acknowledged "indications that the arms embargo established by the Security Council in Resolution 713 (1991) is not being fully observed," ${ }^{24}$ and authorized the deployment of a peacekeeping force. ${ }^{25}$ This proved similarly ineffectual. By May 1992, Serbian forces had begun an aggressive "ethnic cleansing" campaign in Bosnia, and those Bosnian civilians not killed by Serb forces frequently found themselves in concentration camps.

Torture, rape, and executions in the camps were frequent, but it was not until August 1992 that the Security Council took note, in Resolution 771, of "widespread violations of international humanitarian law ... including reports of mass forcible expulsion and deportation of civilians, imprisonment and abuse of civilians in detention centers [and] deliberate attacks on non-combatants." The Council reminded parties to the conflict of their obligations under the Geneva Conventions, and - as it had done nearly two years earlier in Resolution 670 on Iraq - it reiterated the principle of individual liability for those who committed or ordered grave breaches of the Geneva Conventions. ${ }^{26}$

In October 1992, the Council declared a no-fly zone over Bosnia, ${ }^{27}$ but only in March 1993 did the Council authorize the use of force by member states to enforce the no-fly zone. ${ }^{28}$ By spring 1993 , it was no longer possible to view the violence in the Former Yugoslavia as a minor matter. The Council noted the government of Yugoslavia's responsibility to prevent "the commission of the crime of genocide," and condemned "ethnic cleansing," the "brutal actions of Bosnian Serb paramilitary units," and "the continued deliberate armed attacks and shelling of the innocent civilian population by Bosnian Serb paramilitary units." ${ }^{29}$ On May 25, in Resolution

24 UN Security Council Resolution 740, S/RES/74o, Feb. 7, 1992. Adopted unanimously.

25 UN Security Council Resolution 743, S/RES/743, Feb. 21, 1992. Adopted unanimously.

26 UN Sccurity Council Resolution 771, S/RES/771, Aug. 13, 1992. Adopted unanimously

27 UN Security Council Resolution 781, S/RES/781, Oct. 9, 1992. Adopted 14-0-1, with China abstaining.

${ }_{28}$ UN Security Council Resolution 816, S/RES/816, Mar. 31, 1993. Adopted 14-0-1, with China abstaining.

29 UN Security Council Resolution 819, S/RES/819, Apr. 16, 1993. Adopted unanimously. 
827 , the Council authorized the creation of an international tribunal to prosecute "persons responsible for serious violations of international humanitarian law" in the Former Yugoslavia. The Council did this under its Chapter VII authorities, asserting that such a criminal tribunal "would contribute to the restoration and maintenance of peace." 30

In the short term, the establishment of the Ad Hoc International Criminal Tribunal for the Former Yugoslavia (ICTY) did no such thing. Ethnic cleansing and other crimes against civilians continued. Finally, in June 1993, the Council authorized the UN Protection Force (UNPROFOR) to use force "to ensure the protection of the civilian population" and protect civilians in designated safe areas. ${ }^{31}$ Fatefully, one of those safe areas was the town of Srebrenica; the Council had previously insisted that "all parties and others concerned treat Srebrenica and its surroundings as a safe area which should be free from any armed attack or any other hostile act." ${ }^{2}$

Meanwhile, thousands of miles away, conditions in distant Somalia were deteriorating as well. With the ouster of long-time dictator Mohammed Siad Barre by rival tribal militias in January 1991, Somalia was gripped by chaotic violence. Drought and conflict disrupted crops and food supplies and spread disease. Soon, millions were displaced, hunger and disease were rampant in civilian populations, and violence began to claim thousands of lives. Andrew Natsios, former Administrator of the US Agency for International Development, called Somalia " $[t]$ he worst humanitarian disaster in the world today." 33

As in the Former Yugoslavia, the Security Council's initial response to the Somali crisis was halting: an arms embargo was imposed in January 1992, ${ }^{34}$ followed by efforts to promote a cease-fire between warring parties, deliver humanitarian aid, and create a UN presence on the ground. ${ }^{35}$ By August 1992, the Council was expressing increased concern about "the sporadic outbreak of hostilities leading to continued loss of life" and "the magnitude of human suffering caused by the conflict." Declaring the situation in Somalia a threat to international peace and security, the Council authorized an increase in the size of the UN presence. ${ }^{36}$

In December 1992 the focus on civilian protection sharpened, with the Council, in Resolution 742, "expressing grave alarm $\ldots$ at widespread violations of

$3^{\circ}$ UN Security Council Resolution 827, S/RES/827, May 25, 1993. Adopted unanimously.

${ }_{31}$ UN Security Council Resolution 836, S/RES/836, Jun. 4, 1993. Adopted 13-0-2, with Pakistan and Venezuela abstaining.

32 S/RES/819; UN Security Council Resolution 824, S/RES/824, May 6, 1993. Adopted unanimously.

33 Physicians for Human Rights, Somalia, No Mercy in Mogadishu: The Human Cost of the Conflict 6 the Struggle for Relief, Africa WATch (Mar. 26, 1992).

34 UN Security Council Resolution 733, S/RES/733, Jan. 23, 1992. Adopted unanimously.

35 UN Security Council Resolution 746, S/RES/746, Mar. 17, 1992; UN Security Council Resolution 767 , S/RES/767, Jul. 24, 1992; Security Council Resolution 775, S/RES/775, Aug. 28, 1992. All adopted unanimously.

${ }^{36} \mathrm{~S} / \mathrm{RES} / 775$. 
international humanitarian law," including violence against UN and other humanitarian personnel, "deliberate attacks on non-combatants," and the "impeding of the delivery of food and medical supplies essential for the survival of the civilian population." The Council again reiterated the principle of individual liability for violations of international humanitarian law. Acting under Chapter VII, the Council also authorized member states to "use all necessary means to establish as soon as possible a secure environment for humanitarian relief operations in Somalia" and called on states to contribute military forces for that purpose. ${ }^{37}$

Soon, thousands of international troops were on the ground in Somalia, led by the 25,000-strong contingent from the United States. In March 1993, top faction leaders signed the Addis Ababa Accords, agreeing to a cease-fire, and the Security Council authorized an expanded mandate for international troops, including the disarmament of militias and the reestablishment of law, order, and representative government. Command shifted from the United States to the UN, and the United States withdrew all but a few thousand troops. Violence against civilians and humanitarian convoys continued, however, and in July 1993, twenty-four Pakistani troops under UN command were massacred by the forces of warlord Mohamed Farrah Aidid.

By the summer of 1993, the UN had its hands full both in Somalia and in the Former Yugoslavia. In both cases, the "new world order" was proving more difficult than imagined - or, at any rate, it was becoming increasingly apparent that political unity among Security Council members would only go so far. The sheer complexity of the conflicts in Somalia and the Former Yugoslavia stymied the Council's initial efforts to restore peace. Unlike Iraq's 1990 invasion of Kuwait, these were not relatively tidy, straightforward conflicts between the uniformed armed forces of states; these were brutal, messy, multiparty internal conflicts driven by ethnic rivalries and competition for scarce resources.

Subsequent events in Somalia and Bosnia are too well-known to require much discussion here (Chapter 11 offers a detailed account of UN Security Council actions in Bosnia and Herzegovina). For current purposes, it is sufficient to note that in both situations, Security Council efforts to protect civilians were, for the most part, failures.

In Somalia between 1991 and 1992, an estimated 350,000 people died as a result of conflict, famine, and disease. ${ }^{38}$ The spring 1993 massacre of UN troops from Pakistan led US and UN forces to attack Aidid's strongholds, and in October 1993, a bloody urban battle with Aidid's forces led to the deaths of eighteen US soldiers. The United States responded by declaring an intent to withdraw all US troops from Somalia, leaving only a small UN force on the ground. In January 1994, outgoing UN Commander Lieutenant General Cevik Bir of Turkey declared, in a letter to UN Secretary-General Boutros Boutros-Ghali, that UN efforts to disarm clan

37 UN Security Council Resolution 794, S/RES/794, Dec. 3, 1992. Adopted unanimously.

$3^{8}$ Milton Leitenberg, Deaths in Wars and Conflicts in the 20TH Century (Cornell University Press, 2006, 3rd Edition), 8. 
militias had failed. Boutros-Ghali himself offered a qualified defense of UN activities in Somalia: "It has been a difficult mission that did not attain all the objectives that the Security Council set for it," he acknowledged, but he went on to blame the Somalis themselves rather than the UN: "As far as national reconciliation is concerned, the international community ... strove to create an environment conducive for the Somali leaders to achieve this goal. [But] if the political will to achieve a durable compromise was lacking, the responsibility lies with the Somali leadership." 39

By 1995, the remaining UN troops were also withdrawn. UN assistance undoubtedly saved civilian lives, but war and conflict-related deaths continued. As Human Rights Watch noted in 2013, "Somalia's long-running armed conflict continues to leave civilians dead, wounded, and displaced in large numbers." ${ }^{\circ}$

In Bosnia, the ongoing horrors culminated in the July 1995 Srebrenica massacre, in which an estimated 8,000 unarmed Bosnian men and boys were slaughtered by Bosnian Serb forces, under the noses of the Dutch UN peacekeeping troops sent to protect the Srebrenica "safe zone." This finally led the Security Council to authorize an aggressive, NATO-led air campaign against Serbian and Bosnian Serb targets, and the subsequent bombings ultimately brought Serbian leaders to the negotiating table in November 1995. On November 21, the Dayton Accords brought an ambiguous end to the lengthy conflict - but by then, the war in Bosnia had killed over 100,000 people, at least half of whom were civilians; another 20,000 are estimated to have died in the Croatian wars. ${ }^{41}$

Commenting on UN failures in the Former Yugoslavia, the UN SecretaryGeneral warned that "when peacekeeping operations are used as a substitute for ... political consensus they are likely to fail." In Bosnia, the Security Council expected peacekeepers to keep the peace, but "there was no peace to keep." The "Security Council obviously expected that the 'warring parties' on the ground would respect the authority of the United Nations and would not obstruct or attack its humanitarian operations. It soon became apparent that, with the end of the cold war and the ascendancy of irregular forces - controlled or uncontrolled - the oid rules of the game no longer held." ${ }^{2}$

Of course, the Security Council's failures in Somalia and Bosnia paled in comparison to its failures during the 1994 Rwandan genocide. Chapter 10 offers a detailed discussion of Security Council action - or inaction - with regard to Rwanda, but here again, the basic facts are now all too well-known. The 1993 deaths

39 UN Security Council, Report of the Secretary-General on the Situation in Somalia Submitted in Pursuance of Paragraph 13 of Security Council Resolution 954 (1994), S/1995/231, Mar. $28,1995$.

40 Human Rights Watch, World Report 2013: Somalia, Jan. 2013, 1.

4" Robert M. Hayden, "Ethnic Cleansing" and "Genocide," $17(6)$ European Journal of Public HeALTH 546 (2007).

+2 UN General Assembly, Report of the Secretary-General Pursuant to General Assembly Resolution 53/35: The Fall of Srebrenica, A/54/549, Nov. 15, 1999. 
of Pakistani peacekeepers and US troops in Somalia left both the United States and the UN reluctant to risk embroiling ground troops in complex ethnic conflicts, a situation Rwanda's Hutu genocidaires were quick to exploit. On April 7, 1994, ten Belgian UN peacekeeping soldiers were murdered by Rwandan Hutu soldiers. A week later, Belgium withdrew its remaining soldiers, and a week after that, the UN reduced the size of its peacekeeping contingent by 90 percent. ${ }^{43}$ Unwilling to commit additional resources - and distracted by the increasingly dire situation in Bosnia - the Security Council essentially ignored the Rwandan genocide. As a result, some 800,000 people were slaughtered in a matter of months.

The Rwandan genocide cast a long shadow, and in 1995, that shadow further darkened the world's response to the Srebrenica massacre. Once again, unarmed civilians had been remorselessly slaughtered by militias with nothing but contempt for international humanitarian law. Once again, UN peacekeepers had been too few and too poorly resourced to make a difference. Once again, decision makers in New York, Washington, and major national capitals were unwilling to take the risks associated with more robust interventions. And once again, UN peacekeepers were seen to essentially cut and run, abandoning their civilian charges.

A subsequent independent commission of inquiry into $\mathrm{UN}$ actions during the Rwanda genocide was blunt in its assessment:

The systematic slaughter of men, women and children which took place over the course of about 100 days between April and July of 1994 will forever be remembered as one of the most abhorrent events of the twentieth century ... The failure by the United Nations to prevent, and subsequently, to stop the genocide in Rwanda was a failure by the United Nations system as a whole ... there was a persistent lack of political will by Member States to act, or to act with enough assertiveness. ${ }^{44}$

In contrast to Boutros-Ghali's defensiveness on Somalia, UN Secretary-General Kofi Annan was as unsparing as the commission of inquiry in his own later critique of UN failures in Rwanda:

The United Nations was founded at the end of a war during which genocide had been committed on a horrific scale. Its prime objective was to prevent such a conflict from ever happening again. Three years later, the General Assembly adopted a Convention under which States accepted an obligation to "prevent and punish" this most heinous of crimes.

In 1994, the whole international community - the United Nations and its Members States - failed to honour that obligation. Approximately 800,000 Rwandans were slaughtered by their fellow countrymen and women, for no other reason than that they belonged to a particular ethnic group. That is genocide in its purest and most evil form.

43 Timeline: 100 Days of Genocide, BBC NEws, Apr. 6, 2004

+ UN Security Council, Report of the Independent Inquiry into the Actions of the United Nations during the 1994 Genocide in Rwanda, S/1999/1257, Dec. 15, 1999. 
All of us must bitterly regret that we did not do more to prevent it. There was a United Nations force in the country at the time, but it was neither mandated nor equipped for the kind of forceful action which would have been needed to prevent or halt the genocide. On behalf of the United Nations, I acknowledge this failure and express my deep remorse. ${ }^{45}$

The "new world order" heralded by US President George H.W. Bush had proved illusory. After Somalia, Bosnia, and Rwanda, who could truthfully claim that the UN Security Council was committed to civilian protection?

\section{SOUL-SEARCHING AND GUILT}

The UN's failures in Somalia, Bosnia, and Rwanda triggered a period of soulsearching, both for UN officials and for many of the Security Council's permanent members. Importantly, the UN's failures were recognized as precisely that: virtually no one, looking at Srebrenica and Rwanda, was willing to argue that the mass slaughter of civilians was a subject with which the Security Council should not concern itself - or that the Security Council's belated half-measures were sufficient.

For one thing, it was apparent that the consequences of genocide and ethnic cleansing tend to spill across state borders and have a profoundly destabilizing effect. As the Security Council itself had observed at its January 1992 summit meeting, "the absence of war and military conflicts among states [will] not in itself ensure international peace and security." ${ }^{6}$ For another, a normative evolution was in the process of occurring: in the human rights era, it was no longer obvious that the principle of nonintervention should trump the urgent needs of human beings. Toleration of mass atrocities no longer seemed acceptable - it seemed immoral.

This normative evolution was driven in part by the rise of increasingly influential international human rights NGOs, and accelerated by the emergence of a globalized, $24 / 7$ media. In the era of fax machines, the Internet, and CNN (which, coming to prominence during the 1991 Gulf War, was itself a herald of the "new world order" in a very different sense), tragedies and crimes in even the furthest corner of the globe could become almost instantly known around the world. The combination of a globalized media and an increasingly sophisticated human-rights NGO community put tremendous pressure upon the UN and the Security Council's permanent members: after Rwanda, after Srebrenica, how would they ensure that this time, "never again" truly meant never again?

Between 1995 and 1998, much of the UN's shame over earlier failures was channeled into a determination to ensure accountability for the perpetrators of atrocities. The Security Council had created the ICTY in 1993, and in November

45 Press Release, Kofi Annan Emphasizes Commitment to Enabling UN Never Again to Fail in Protecting Civilian Population from Genocide or Mass Slaughter, SG/SM/7263, AFR/196, Dec. 16, 1999.

$4^{6}$ UN Security Council, Note by the President of the Security Council, S/23500, Jan. 31, 1992. 
1994, the Council created a similar criminal tribunal to adjudicate crimes committed in Rwanda. ${ }^{+7}$ The creation of these two ad hoc tribunals renewed international interest in the development of a standing International Criminal Court (ICC), and by 1996 , a preparatory committee on the establishment of such a court had been established by the UN General Assembly. There followed a series of multilateral preparatory conferences attended by interested states, and ultimately, in July 1998 , 120 states voted to adopt the Rome Statute creating the ICC. ${ }^{48}$ (Chapter 7 discusses the creation and work of these various international criminal tribunals in greater detail.)

During this same period, the Security Council also showed an increasingly broad concern with civilian protection. As Jared Genser and Bruno Stagno Ugarte noted in Chapter 1 , the Council began to invite briefings from a widening range of organizations with a humanitarian focus, "progressively issued invitations under Rule 39 of its Provisional Rules of Procedure to an ever larger circle of briefers, including the International Committee of the Red Cross (ICRC) on August 15, 1996, the United Nations Children's Fund (UNICEF) on May 21, 1997, and the Special Representative on Children and Armed Conflict on June 29, 1998."4) In June 1998 , the Council also added the thematic issue of children and armed conflict to its agenda, and in February 1999, it added "Protection of Civilians in Armed Conflict." ${ }^{\circ \circ}$

But even as the international community was going through a period of soulsearching, trouble was again brewing in the Former Yugoslavia. This time, the emerging crisis was in Kosovo, a Serbian province occupied predominantly by ethnic Kosovar Albanians, who made up roughly 90 percent of the province's population. Under Former Yugoslav leader Marshall Tito, the province had been granted substantial political and cultural autonomy, but this was virtually eliminated in 1989 by Slobodan Milošević. Following an unsuccessful effort by the Kosovars to declare independence, the Milošević regime cracked down on Kosovar Albanians, dismissing them from public employment and instituting an era of ethnic discrimination and repression.

Beginning in 1995, the insurgent Kosovo Liberation Army (KLA) began to attack Serbian targets, and the Yugoslav authorities - and Serbian paramilitary groups responded with increasing ruthlessness. In March 1998, the Security Council, citing its Chapter VII authorities, passed Resolution 1160, condemning both "the use of excessive force by Serbian police forces against civilians and peaceful demonstrators in Kosovo, as well as all acts of terrorism by the Kosovo Liberation Army." Resolution

${ }^{47}$ UN Sccurity Council Resolution 955, S/RES/955, Nov. 8, 1994. Adopted 13-1-1, with Rwanda voting against and China abstaining.

${ }^{8}$ Rome Statute of the Intemational Criminal Court, A/CONF.183/9, 2187 U.N.T.S. 9o, entered into force July, 1, 2002. The United States, infamously, was one of only seven states to vote against.

49) Cliapter 1.

so Chapter 1. 
1160 imposed an arms embargo on Yugoslavia ("including Kosovo") and raised the possibility that "additional measures" might be needed in the future..$^{51}$

This did little to discourage either the Serbians or the KLA. By late 1998 , the escalating violence had left hundreds dead, ${ }^{52}$ destroyed homes in hundreds of Kosovar villages, and displaced thousands of Kosovar Albanians, many of whom fled to neighboring Albania and Macedonia. ${ }^{53}$ In September 1998, the Security Council expressed its dismay in Resolution 1199, declaring itself "gravely concerned at the recent intense fighting in Kosovo and in particular the excessive and indiscriminate use of force by Serbian security forces and the Yugoslav Army which have resulted in numerous civilian casualties and ... the displacement of over 230,000 persons from their homes." 54 It went on to again declare its intent "to consider further action and additional measures to maintain or restore peace and stability in the region" should the situation not improve. The speed with which the Council responded to the violence in Kosovo seemed to send a clear message: this time, mass atrocities against civilians would not be allowed to continue.

As it turned out, however, Resolution 1199 marked the end of Security Council action on the Kosovo crisis. As the NATO powers began to consider the possibility of once again stopping Milošević through an air campaign - a tactic that had ultimately, if belatedly, worked in 1995 - Russia, long a Yugoslav and Serbia ally, grew concerned that the NATO states, biased against Serbia, were rushing headlong toward the use of force. Russia made it clear to the NATO states that it would veto any Security Council resolution authorizing the use of force to resolve the crisis. ${ }^{55}$

In January 1999, the mass killing of forty-five Kosovar civilians in the town of Racak triggered a round of frantic but inconclusive diplomacy. ${ }^{56}$ By February, OSCE monitors were reporting "a significant build-up of [Yugoslav Army] forces throughout Kosovo leading to the arming of civilians and the training of reservists, the arrival of anti-aircraft weapons, the digging of tank pits and the preparation of demolition explosives along key routes in from the south and an increase in military air activity." Within NATO, fears mounted: unchastened by the 1995 bombing campaign, the Milošević regime seemed poised to launch another large-scale

${ }_{51}$ UN Security Council Resolution 1160, S/RES/1160, Mar. 31, 1998. Adopted 14-0-1, with China abstaining.

52 The death toll is unknown, but Human Rights Watch estimates that between the beginning of 1998 and March 1999, 1,500-2,000 people were killed. Human Rights Watch, Under Orders: War Crimes in Kosovo, Oct. 26, 2001.

53 Human Rights Watch's 2001 World Report noted that "[a]ccording to a November 1998 survey of 28 , villages in Kosovo carried out jointly by UNHCR and a group of humanitarian NGOs, 210 villages had been affected by the fighting [as of November] 1998. 28 percent of the homes in those villages ( 9,809 ) had been completely destroyed, and 15 percent $(5,112)$ of the homes had severe damage. Ibid.

s4 UN Security Council Resolution 1199, S/RES/1199, Sept. 23, 1998. Adopted 4-0-1, with China abstaining.

55 Martin A. Smith and Paul Latawski, The Kosovo Crisis: The Evolution of Post Cold War European SEcurity (Manchester University Press, 2004), ch.2: Kosovo, NATO and Russia.

${ }^{56}$ Smith and Latawak, The Kosovo Crisis. 
ethnic-cleansing campaign, this time with a view toward driving ethnic Kosovars out of Kosovo and "reclaiming" the province for ethnic Serbs.

On March 18, 1999, when Yugoslav authorities refused to sign the Rambouillet Peace Agreement painstakingly negotiated by the United States and the United Kingdom, NATO faced a dilemma. On the one hand, there seemed to be no point in seeking a Security Council resolution authorizing NATO to use force to halt Yugoslav and Serbian aggression against Kosovar civilians; Russia, and perhaps China, would certainly veto any such resolution. On the other hand, after the shameful failures to stop the Rwandan genocide or prevent the massacre at Srebrenica, standing idly by during another ethnic cleansing campaign seemed unacceptable.

NATO opted to place civilian protection considerations over considerations of legality. On March 24, 1999, it commenced an aggressive campaign of aerial bombing against Serbian targets both in Kosovo and in Belgrade. Initially, the reaction from Yugoslav forces and Serbian paramilitaries was to escalate their attacks on the Kosovar Albanian population. As Human Rights Watch reported:

The state-organized campaign that began in late March 1999 was ... different in scale and scope than the violence that had occurred in 1998 and early $1999 \ldots$. Serbian and Yugoslav forces carried out a systematic campaign of violence and forcible depopulation that left an estimated 80 percent of the civilians displaced from their homes. Areas with no history of support for the KLA and which had previously escaped the violence in Drenica and southwestern Kosovo, such as Pristina and eastern Kosovo, were targeted for mass expulsion .... In short, localized counterinsurgency was joined by systematic "ethnic cleansing." 57

Ultimately, however, the relentlessness of NATO's air campaign forced Milošević to back down. In early June, he agreed to withdraw Yugoslav troops from Kosovo and allow NATO peacekeeping troops into the province. As the Yugoslav army withdrew and NATO troops poured in, Kosovar refugees returned more or less en masse. Although some 10,000 Kosovars are estimated to have died prior to Milošević's capitulation, most observers agreed that without NATO's intervention, the death toll would likely have been far worse (Chapter 15 discusses Kosovo in greater detail).

Needless to say, the success of the NATO intervention was hardly a success for the Security Council. NATO authorities had carefully refrained from offering a legal theory justifying their actions, but few doubted that NATO's use of force was, at best, of dubious legality, and, at worst, a clearly unlawful violation of the UN Charter and international law. ${ }^{58}$ The NATO member states had simply bypassed the Security Council altogether. Yet just as few were prepared to offer a defense of the legality of

57. Human Rights Watch, Under Orders.

;s Frederic L. Kirgis, The Kosovo Situation and NATO Militan Action, American Society of International Law (Mar. 1999); Christoph Schreuer, Is There a Legal Basis for the NATO Intervention in Kosovo?, I INTtrna'tonal Law Forum 151 (1999); David Wippman, Kosovo and the Limits of Intemational Law, 25 (1) Fordiam INTkr.ational Law Journal 129 (2001). 
NATO action, few were prepared to condemn the intervention outright; after all, it appeared to have saved thousands of lives. Perhaps, argued some scholars, it was not lawful but nevertheless "legitimate." 59

The Council itself made the best of a bad bargain. On June 10, 1999, it passed Resolution 1244 by a unanimous vote, with only China abstaining. In the resolution, it "welcomed" the agreement between NATO and Yugoslavia, "decided" to deploy peacekeeping troops under UN auspices, and "authorize[d] Member States and relevant international organizations" - for example, NATO - "to establish the international security presence in Kosovo ... with all necessary means to fulfill its responsibilities." Those responsibilities were broad, and included "[d]eterring renewed hostilities, maintaining and where necessary enforcing a ceasefire, and ensuring the withdrawal and preventing the return into Kosovo of Federal and Republic military, police and paramilitary forces ... Demilitarizing the Kosovo Liberation Army (KLA) ... Establishing a secure environment [and] ... Ensuring public safety and order until the intemational civil presence can take responsibility for this task." In effect, the province of Kosovo became a ward of NATO.

NATO's Kosovo intervention launched yet another period of soul-searching within the international community, this time over the legitimacy and legality of humanitarian interventions. UN Secretary-General Kofi Annan captured the dilemma poignantly in a September 1999 speech:

We need to adapt our international system better to a world with new actors, new responsibilities, and new possibilities for peace and progress. State sovereignty, in its most basic sense, is being redefined - not least by the forces of globalization and international co-operation. States are now widely understood to be instruments at the service of their peoples, and not vice versa... When we read the Charter today, we are more than ever conscious that its aim is to protect individual human beings, not to protect those who abuse them....

The genocide in Rwanda showed us how terrible the consequences of inaction can be in the face of mass murder. But this year's conflict in Kosovo raised equally important questions about the consequences of action without international consensus and clear legal authority. It has cast in stark relief the dilemma of so-called "humanitarian intervention." On the one hand, is it legitimate for a regional organisation to use force without a UN mandate? On the other, is it permissible to let gross and systematic violations of human rights, with grave humanitarian consequences, continue unchecked?

The Kosovo conflict and its outcome have prompted a debate of worldwide importance. And to each side in this debate difficult questions can be posed. To those for whom the greatest threat to the future of international order is the use of

59 See Tania Voon, "Legitimacy and Lawfulness of Humanitarian Intervention" in Michael C. Davis (ed.), International Intervention in the Post-Cold War World: Moral Responsibility and Power Polrtics (M.E. Sharpe, 2004); Christopher S. Biggers, If the Intervention in Kosovo Was Morally Legitimate, Does It Matter if It Was Illegal?, London School of Economics (2008).

to UN Security Resolution 1244, S/RES/1244, Jun. 10, 1999. Adopted 14-0-1, with China abstaining. 
force in the absence of a Security Council mandate, one might say: leave Kosovo aside for a moment, and think about Rwanda. Imagine for one moment that, in those dark days and hours leading up to the genocide, there had been a coalition of states ready and willing to act in defence of the Tutsi population, but the Council had refused or delayed giving the green light. Should such a coalition then have stood idly by while the horror unfolded?

To those for whom the Kosovo action heralded a new era when states and groups of states can take military action outside the established mechanisms for enforcing international law, one might equally ask: Is there not a danger of such interventions undermining the imperfect, yet resilient, security system created after the second world war, and of setting dangerous precedents for future interventions without a clear criterion to decide who might invoke these precedents and in what circumstances? $^{6 \mathbf{r}}$

The debate over humanitarian intervention went on, unresolved - as did several long-simmering conflicts, including those in northern Uganda, Liberia, Sudan, ${ }^{62}$ East Timor, and Sierra Leone, all involving large-scale abuses against civilian populations. Although few of these conflicts generated the degree of urgency or controversy that had characterized the run-up to the Kosovo intervention, the Council was closely engaged with several. In East Timor, for instance, a 1999 referendum in which the Timorese people voted for independence from Indonesia led to large-scale violence, mostly perpetrated by pro-Indonesian militias. The Council responded with Resolution 1264 , authorizing (under Chapter VII) an Australian-led multinational force to restore peace and security. Notably, however, Resolution 1264 was passed only once the Indonesian government grudgingly acquiesced to the presence of international troops, thus avoiding the sovereignty issues that might otherwise have scuppered Council action. ${ }^{63}$

In Sierra Leone, the Council in October 1999 responded to the country's brutal civil war by expanding the mandate of UN peacekeeping forces to include civilian protection, ${ }^{6}{ }^{4}$ but it was only when UNAMSIL troops came under direct attacks and several hundred UN peacekeepers were taken hostage by the Revolutionary United Front (RUF) in 2000 that the Council drastically increased its commitment to Sierra Leone, ${ }^{65}$ authorizing UNAMSIL to use force against the RUF as needed to "deter

61 Two Concepts of Sovereignty, THE Economist, Sept. 16, 1999.

62 James Traub, Unwilling and Unable: The Failed Response to the Atrocities in Darfur, Global Centre for the Responsibility to Protect (2010).

${ }^{63}$ Ian Martin, "International Intervention in East Timor" in Jennifer M. Welsh (ed.), Humanitarian Intervention and International Relations (Oxford University Press, 2004), 142-162.

${ }^{64}$ Paul Williams, Fighting for Freetown: British Military Intervention in Sierra Leone, 22(3) CONTEMPORARY SECURITY PolicY 140 (2001); UN Security Council Resolution 1270, S/RES/1270, Oct. 22, 1999, adopted unanimously.

${ }^{65}$ See UN Security Council Resolution 1299, S/RES/1299, May 19, 2000; UN Security Council Resolution 1313, S/RES/1313, Aug. 4, 2000; UN Security Council Resolution 1334, S/RES/1334, Dec. 22, 2000; UN Security Council Resolution 1346, S/RES/1346, Mar. 30, 2001. All adopted unanimously. 
and, where necessary, decisively counter the threat of RUF attack by responding robustly to any hostile actions or threat of imminent and direct use of force."

Here again, however, the Council was largely saved from difficult decisions by the decisive action of British forces sent in, initially, to evacuate British personnel. As RUF attacks on UNAMSIL increased and several British personnel were taken hostage, British troops (including, eventually, Special Forces soldiers) struck back, mounting several successful rescue operations and substantially damaging RUF capabilities and morale. Ultimately, British actions helped push the RUF to accept a cease-fire agreement in fall 2000 . Strictly speaking, British actions were unsanctioned by the Security Council, but Council members were too grateful to the British for - literally - rescuing a failed peacekeeping operation to be overscrupulous. ${ }^{67}$

Though it managed to duck many of the most difficult issues raised by Kofi Annan, the Security Council steadily increased its thematic focus on civilian protection beginning in 1999. In August 1999, it passed Resolution 1261 (1999) on Children and Armed Conflict, condemning "the targeting of children in situations of armed conflict, including killing and maiming, sexual violence, abduction and forced displacement, recruitment and use of children in armed conflict." ${ }^{68}$ And one day after Kofi Annan's speech on the dilemma of humanitarian intervention the Council passed Resolution 1265 on the "Protection of Civilians in Armed Conflict." ${ }^{\text {69 }}$

Resolution 1265 marked the Council's first explicit effort to develop a "theory" of civilian protection. In Resolution 1265, the Council made it clear that harm to civilians would no longer be viewed as an occasional, if regrettable, concomitant to armed conflicts, but instead as a problem arising out of the changing nature of armed conflict, with implications for the changing nature of threats to international peace and security. The Council noted "that civilians account for the vast majority of casualties in armed conflict and are increasingly targeted by combatants and armed elements" and declared itself "gravely concerned by the hardships borne by civilians during armed conflict, in particular as a result of acts of violence directed against them." It "recognize[ed] the consequent impact this will have on durable peace, reconciliation and development." While acknowledging its "primary responsibility under the Charter of the United Nations for the maintenance of international peace and security," it "underlin[ed] the importance of taking measures aimed at conflict prevention and resolution." 70

See generally Gilles Yabi, "Sierra Leone" in Blanca Antonini (ed.), Security Council Resolutions under Chapter VII: Design, Implementation and Accountabilities (FRIDE, 2009).

${ }^{66} \mathrm{~S} / \mathrm{RES} / 1313$.

${ }_{7}$ UN Security Council Provisional Verbatim Record of the 4139th Meeting, S/PV.4139, May 11, 2000.

68 UN Security Council Resolution 1261, S/RES/1261, Aug. 25, 1999. Adopted unanimously.

69 UN Security Council Resolution 1265, S/RES/1265, Sept. 17, 1999. Adopted unanimously.

$7^{\circ}$ UN Security Council Resolution 1265. 
This simple statement had potentially far-reaching implications. If failures to protect civilians undermine durable peace, then protecting civilians is an integral part of maintaining international peace and security - and if the aperture is broadened to include protection, then, notwithstanding the nonintervention principles enshrined in Article 2(7) of the UN Charter, virtually everything falls within the Security Council's zone of authority.

Indeed, Resolution 1265 went on to note "the need to address the causes of armed conflict in a comprehensive manner in order to enhance the protection of civilians on a long-term basis, including by promoting economic growth, poverty eradication, ststainable development, national reconciliation, good governance, democracy, the rule of law and respect for and protection of human rights." It called on states to ratify "the major instruments of international humanitarian, human rights and refugee law, and to take appropriate legislative, judicial and administrative measures to implement these instruments domestically," and "the responsibility of States to end impunity and to prosecute those responsible for genocide, crimes against humanity and serious violations of international humanitarian law." Finally, it stated its "willingness to respond to situations of armed conflict where civilians are being targeted or humanitarian assistance to civilians is being deliberately obstructed, including through the consideration of appropriate measures at the Council's disposal in accordance with the Charter of the United Nations" - a clear reference to coercive measures, including the use of force. ${ }^{7}$

Thus, civilian protection concems became a vehicle for a further chipping away at traditional notions of sovereignty. From a normative perspective, at least, Resolution 1265 represented a dramatic shift in the Council's conception of its own role. No longer did it see itself as, most fundamentally, the guarantor of interstate peace. From 1999 on, it defined itself in significant part by its commitment to preventing conflict-related harm to individuals, at least when such harm occurred on a large scale. Indeed, some have argued that civilian protection has now become "the pre-eminent norm in the international legal regime." 72

Since 1999, the effort to define, theorize, and contextualize civilian protection norms and best practices has become a veritable cottage industry, both within UN circles and in academic institutions and regional and nongovernmental organizations. Other organizations have in fact far surpassed the Council in the depth and sophistication of their work on civilian protection, and expertise and practical experience on the subject has grown exponentially within organizations such as the United Nations High Commissioner for Refugees (UNHCR), Office for the Coordination of Humanitarian Affairs (OCHA), Office of the High Commissioner

UN Sccurity Council Resolition 1265.

" Fidwin Bikundo, "The Responsibility to Protect Civilians from Political Violence: Locating Necessity between the Rule and Its Fixception" in Angus Francis, Vesselin Poporski, and Clairles Simpford

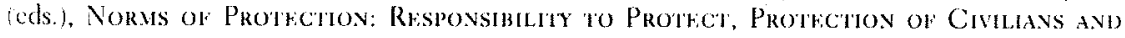
Thitir Initeraction (United Nations University Press, 2012). 
for Human Rights (OHCHR), UNICEF, and Department of Peacekeeping Operations (DPKO). Inevitably, the concept even garnered its own acronym, "PoC," for the "protection of civilians."

Meanwhile, the Security Council's concern with civilian protection has been manifested with increasing frequency. Although the Security Council made only a handful of references to civilian protection concerns prior to the 199os, from 1999 to the present the resolutions referencing civilian protection concerns number in the hundreds - far too many to highlight individually. The Council has received several thematic reports on civilian protection from the UN Secretary-General, ${ }^{73}$ and has followed Resolution 1265 with three additional thematic resolutions on civilian protection. ${ }^{7+}$ In addition, civilian protection has been highlighted in numerous presidential statements ${ }^{75}$ and forms a part of the mandates of a number of UN missions ${ }^{76}$ and peacekeeping operations, including those in Liberia, Sierra Leone, Congo, Burundi, Sudan, Chad, Côte d'Ivoire, and the Central African Republic. ${ }^{77}$

Nevertheless, concerns about sovereignty, principles of nonintervention, and the Council's role in authorizing the use of force continued to shadow discussions of civilian protection in the years immediately following NATO's Kosovo campaign. As Ramesh Thakur, former vice-rector of the United Nations University in Japan, has observed, "the angry and bitter debate in the late 1990 over the so-called

7 Sec, e.g., UN Security Council, Report of the Secretary-General to the Security Council on the Protection of Civilians in Armed Conflict, S/1999/957, Sept. 8, 1999; Report of the Secretan-General to the Security Council on the Protection of Civilians in Armed Conflict, S/2001/331, Mar. 30, 2001; Report of the Secretar-Ceneral to the Security Council on the Protection of Civilians in Amed Conflict, $\mathrm{S} / 2002 / 1300$, Nov. 26, 2002; Report of the Secretary-Ceneral to the Security Council on the Protection of Civilians in Amed Conflict, S/2004/431, May 28, 2004; Report of the Secretany-General on the Protection of Civilians in Amed Conflict, S/2005/740, Nov. 28, 2005; Report of the Secretary-General on the Protection of Civilians in Armed Conflict, S/2007/643, Oct. 28, 2007; Report of the Secretary-Ceneral on the Protection of Civilians in Armed Conflict, S/2009/277, May 29, 2009.

it UN Security Council Resolution 1296, S/RES/1296, Apr. 19, 2000; UN Security Council Resolution 1674, S/RES/1674, Apr. 28, 2006; UN Sccurity Council Resolution 1738, S/RFS/1738, Dec. 23, 2006. All adopted unanimously. For additional examples of Security Council focus on civilian protections, sec also UN Security Council Resolution 1820, S/RES/1820, Jun. 19; 2008; UN Security Council Resolution 1882, S/RES/1882, Aug. 4, 2009; Resolution 1888, S/RES/1888, Sept. 30, 2009; UN Sccurity Council Resolution 1889, S/RES/1889, Oct. 5, 2009; UN Security Council Resolution 1894 , S/RES/1894, Nov, 11, 2009. All adopted unanimously.

75 UN Security Council Presidential Statements S/PRST/1999/6, Feb. 12, 1999; S/PRST/200z/6, Mar. 15 , 2002; S/PRST/2002/4i; S/PRST/2003/27, Dec. 15, 2003; S/PRST/2004/46, Dec. 14, 2004; S/PRST/2005/ 25. June 21, 2005; S/PRST/2009/1, Jan. 14, 2009; and S/PRST/2009/9, Apr. 29, 2009. The Presidential statement of March 15, 2002 (S/PRST/2002/6) endorsed an aide-mémoire proposed by the SecretaryGencral as an instrument of guidance to facilitate the Council's consideration of issues pertaining to the protection of civilians in country-specific situations, in particular relating to peacekecping mandatcs. It listed key objectives for Council action and specific questions for consideration in meeting those objectives. The aide-nicmoire was last revised and endorsed by the Council on November 22, 2010 (S/PRST/2010/25).

;6 UN Missions in Sudan (UNMIS), Darfur (UNAMID), Democratic Republic of Congo (MONUC), Afghanistan, (UNAMA), Central African Republic (MINURCAT), Côte d'lvoire (UNOCI), Liberia (UNMIL), Haiti (MINUSTAH).

-7 Francis, Popovski, and Sampford (eds.), Norms of Protecrion, p. 118. 
challenge of humanitarian intervention highlighted a triple policy dilemma - that is, a threefold protection gap - of complicity, paralysis or illegality., ${ }^{8}{ }^{8}$ In 2001 , however, a groundbreaking new report by the International Commission on State Sovereignty (ICISS) dramatically altered the nature of the debate.

\section{REDEFINING SOVEREIGNTY: THE “RESPONSIBILITY TO PROTECT”}

ICISS began as an ad hoc commission meeting under Canadian auspices. Comprised of a raft of international luminaries - from Ramesh Thakur of India to Gareth Evans of Australia to Cyril Ramaphosa of South Africa - ICISS took as its mission the task of responding to the questions posed in 1999 by Kofi Annan: Could a commitment to protecting populations from crimes such as those that occurred in Bosnia and Rwanda be squared with principles of sovereignty?

In November 2001, ICISS issued a report in which it answered the question by reframing its terms: rather than ask whether sovereignty was in tension with the protection of populations, ICISS simply redefined sovereignty, viewing it, in effect, as a privilege eamed by states that fulfilled their responsibilities to their populations, rather than as a right of states to do as they wished inside their own borders. To ICISS, a state that cannot or will not protect its population from egregious violence has no sovereign right to nonintervention; it is individuals, rather than states, who are viewed as the primary holders of rights. States are legitimated solely by their ability to protect their populations. Thus, to ICISS, "State sovereignty implies responsibility ... Where a population is suffering serious harm, as a result of internal war, insurgency, repression or state failure, and the state in question is unwilling or unable to halt or avert it, the principle of non-intervention yields to the international responsibility to protect." 79

The ICISS report was careful to note that the responsibility to protect (RtoP) was not solely or even primarily about armed interventions. Far from it: RtoP, the report asserted, involves the subsidiary responsibilities to prevent, react, and rebuild, all of which might involve a wide range of actions falling far short of military force. Diplomatic engagement, humanitarian aid, technical assistance, economic sanctions - all these, and more, might be critical to fulfilling RtoP. ICISS emphasized that military intervention should be resorted to only if force was consistent with the traditional principles of "just war" theory: "just cause," "right intention," "last resort," "proportional means," "reasonable prospects," and "right authority."

The ICISS report stressed that if military intervention was necessary, the "right authority" was the UN Security Council. But despite the concerns expressed by Kofi Annan in 1999 mentioned previously, ICISS was unwilling to view Security Council

\footnotetext{
-\$ Francis, Popovski, and Sampford (cds.), Nonus or Protrcrion, forcword by Ramesh Thakur.

- International Commission on Intervention and State Sovercignty, The Responsibility to Protect, Dec. 2001.

\% International Commission on Intervention and State Sovereignty, The Responsibility to Protect.
} 
authorization as an absolute requirement: "If the Security Council rejects a proposal [to intervene to protect a population] or fails to deal with it in a reasonable time, alternative options... [include] action within the area of jurisdiction by regional or sub-regional organizations under Chapter VIII of the Charter, subject to their seeking subsequent authorization." After all, warned ICISS, if the Council "fails to discharge its responsibility to protect in conscience-shocking situations crying out for action," concerned states "may not rule out other means to meet the gravity and urgency of that situation ..."

RtoP remains, in many ways, profoundly appealing from a normative perspective. In numerous ways, the decline of Westphalian sovereignty has been the major headline of twentieth century international legal developments. Over the last century, international law has ceased to be solely a matter of the rights and duties of states vis-à-vis other states - individuals also have entered the international law picture. From the 1940s to the 1990s, the UN Charter's reference to fundamental human rights was steadily elaborated upon in numerous UN resolutions and international human-rights treaties. States began increasingly to accept not only international law limitations on their right to use armed force, but also limitations on their internal sovereignty stemming from the growing body of international humanrights treaties and norms - after the Holocaust, who could defend the position that states could do absolutely whatever they wished inside their own borders?

What is more, international law began to give states obligations to act to prevent human-rights abuses inside the territory of other states: under the Genocide Convention, for instance, which entered into force in 1951, states "undert[ook] to prevent and to punish" genocide. Given this trajectory, the emergence of RtoP seems almost a moral inevitability. States are artificial constructs, but individuals are not. What legitimacy can a state have if it preys upon or fails to protect its own people?

The ICISS report was issued in November 2001, just weeks after the September 11 terrorist attacks on the United States. In some ways, this was hardly a propitious moment for a major new contribution to the 1990s debates over humanitarian intervention - in November 2001, these had been violently shoved into the background, replaced with urgent and seemingly new debates about how to respond to international terrorism. In November 2001, few world leaders or media outlets were interested in a new normative framework for addressing genocide and other mass atrocities; attention was focused instead on the challenges of combating terrorist attacks perpetrated by transnational non-state actors, and on the nascent US war in Afghanistan.

Further, the ICISS report was published just as the United States began to develop new legal rationales for using force for counterterrorism purposes, promulgating the notion of "preemptive" self-defense - and the view that force could

\&1 International Commission on Intervention and State Sovereignty, The Responsibility to Protect. 
lawfully be used inside a sovereign state if that state either consented or was "unwilling or unable" to take appropriate action against terrorists within its borders. The United States has relied on such arguments to justify the cross-border use of force such as drone strikes and raids by special operations forces - far from traditional battlefields.

Note that this argument is similar to RtoP in its assumption that sovereignty implies responsibilities as well as rights, and its further assumption that the great privilege of sovereignty - the right to have other states stay off your territory and out of your internal affairs - can be considered waived by a state that fails to fulfill its fundamental responsibilities. Both this counterterrorism logic and RtoP identify the protection of human beings as the most fundamental responsibility of states. The difference is simply that RtoP focuses on the responsibilities of states to protect their own populations from conflict and atrocities, whereas US counterterrorism arguments have focused on the responsibility of states to refrain from internal acts that threaten the populations of other states, and prevent non-state entities from engaging in such acts inside their borders.

There are obvious differences between RtoP and US arguments about sovereignty and the use of force in the counterterrorism context. Counterterrorism arguments are premised on self-defense, although they stretch traditional concepts of imminent attack almost beyond recognition. RtoP comes from a different tradition. RtoP also places far greater emphasis on nonmilitary responses and - at least in the version that came to be embraced by the UN - on the role of the Security Council as the authorizing entity for the use of force, whereas US counterterrorism arguments support unilateral uses of force.

But RtoP and US counterterrorism arguments about sovereignty and the use of force have undeniable structural similarities. RtoP emphasizes a state's duty to take action inside its own territory to protect its own population from violence and atrocities. US counterterrorism arguments emphasize a state's duty to take action inside its own territory to protect other states' populations from violence. Under both theories, a state that fails in these duties faces the prospect that other states may intervene in its "internal" affairs without its consent. ${ }^{82}$

Given this, universal embrace of the RtoP concept was hardly a foregone conclusion in November 2001. Seen from one vantage point, RtoP was simply a distraction from more pressing counterterrorism concerns. Seen from another, its radical reconceptualization of sovereignty seemed to offer dangerous support, at least in the abstract, to controversial US justifications for using force. ${ }^{83}$

${ }^{82}$ I have written about this elsewhere, see, e.g., Rosa Brooks, Lessons for International Law from the Arab Spring, 28 AMERICAN UNIVERSITY INTERNATIONAL LAW REVIEW 101 (2013).

83 See generally Francis M. Deng, From "Sovereignty as Responsibility" to the "Responsibility to Protect," 2(4) Global Responsibility to Protect 353 (2010); Alex Bellamy, Responsibility to Protect or Trojan Horse? The Crisis in Darfur and Humanitarian Intervention after Iraq, 19(2) ETHICS AND 
Nevertheless, the RtoP concept rapidly gained traction. Although Russia, China, and numerous other states expressed concern about creating a potentially limitless rationale for intervention in states' internal affairs, they were willing to accept at least a somewhat modified version of the RtoP principle. RtoP was endorsed by Kofi Annan, and again endorsed, in somewhat watered-down form, in the 2005 UN World Summit Outcome Document, which was adopted unanimously by the assembled member states. The World Summit Outcome Document restricted the application of RtoP to four particularly egregious crimes (the original ICISS formulation was far broader), and, unsurprisingly, the Outcome Document did not include ICISS language suggesting that in extremis, concerned states could intervene without Security Council authorization. Its language was more restrictive:

138. Each individual State has the responsibility to protect its populations from genocide, war crimes, ethnic cleansing and crimes against humanity. This responsibility entails the prevention of such crimes, including their incitement, through appropriate and necessary means. We accept that responsibility and will act in accordance with it ....

139. The international community, through the United Nations, also has the responsibility to use appropriate diplomatic, humanitarian and other peaceful means, in accordance with Chapters VI and VIII of the Charter, to help to protect populations from genocide, war crimes, ethnic cleansing and crimes against humanity. In this context, we are prepared to take collective action, in a timely and decisive manner, through the Security Council, in accordance with the Charter, including Chapter VII, on a case-by-case basis and in cooperation with relevant regional organizations as appropriate, should peaceful means be inadequate and national authorities are manifestly failing to protect their populations from genocide, war crimes, ethnic cleansing and crimes against humanity. ${ }^{84}$ A year later, the Security Council began to chime in. ${ }^{85}$ In Resolution 1653 (2006) on
Burundi and the Democratic Republic of Congo, it echoed RtoP language, noting that "governments have a primary responsibility to protect their populations." ${ }^{" 86} \mathrm{~A}$ few months later, the Council expressly endorsed RtoP in Resolution 1674, another thematic resolution on protection of civilians: the Council, stated the resolution, "Reaffirms the provisions of paragraphs 138 and 139 of the 2005 World Summit Outcome Document regarding the responsibility to protect populations from genocide, war crimes, ethnic cleansing and crimes against humanity." ${ }^{17}$ The RtoP

INTERnational AfFAIRS 31 (zoo5); Jean Cohen, Whose Sovereignty? Empire versus Intemational Law, 18(3) Ethics AND INTERNational AfFairs 1 (2004).

84 UN. General Assembly, 2005 World Summit Outcome Document, A/6o/L.1, Oct. 24, 2005, 91 138-139.

${ }_{85}$ For a general discussion of the evolution of $\mathrm{R}_{2} \mathrm{P}$ during this period, see generally Louise Arbour, The Responsibility to Protect as a Duty of Care in Intemational Law and Practice, 34(3) Review of INTERNATIONAL STUDIES 445 (2008).

86 UN Security Council Resolution 1653, S/RES/1653, Jan. 27, 2006. Adopted unanimously.

87 S/RES/1674 
concept was again endorsed, using virtually identical language in 2009, in Resolution $1894^{88}$

This increased Council focus on RtoP did not translate consistently into action to protect civilians, either on RtoP ground or on more traditional grounds, of course. In 2009, the Council essentially ignored the Sri Lankan government's indiscriminate attacks on civilians in a spring push to destroy the Tamil Tigers insurgency; ${ }^{89}$ the two-and-a-half decade-long armed conflict left an estimated 80,000-100,000 dead, as many as half of whom may have been civilians. ${ }^{\circ \circ}$ The UN spokesman in Sri Lanka called the events of spring 2009 "a bloodbath." responded with prompt concern (albeit not using RtoP language) when Guinean forces fired on a crowd of protestors later the same year ${ }^{92}$ - although confirmed deaths in the violence in Guinea were fewer than 200. ${ }^{93}$

In 2011, the Security Council for the first time relied upon RtoP principles to justify a military intervention authorized under Chapter VII. When the Libyan government cracked down violently on peaceful political protesters in February 2011, it sparked an all-out rebellion against the regime of long-time strongman Muammar Qaddafi. The violence escalated rapidly, with Libyan government forces indiscriminately attacking population centers in an effort to destroy the growing rebel movement. Qaddafi declared that he would go "door to door" if necessary, showing "no mercy" to those who opposed him. ${ }^{44}$

Unlike in prior situations - Bosnia, Rwanda, Kosovo - the Security Council took rapid action as evidence of civilian deaths and the deliberate targeting of civilians mounted. (Libya is discussed extensively in Chapter 17.) In Resolution 1970, passed on February 26, 2011, the Council noted "the Libyan authorities' responsibility to protect its population" and declared that "the widespread and systematic attacks currently taking place in the Libyan Arab Jamahiriya against the civilian population may amount to crimes against humanity." Resolution 1970 referred the situation in Libya to the International Criminal Court, and imposed an arms embargo and a range of sanctions on the Libyan regime, including an arms embargo. ${ }^{95}$

This failed to induce Qaddafi to comply, and on March 17, 2011 - less than a month later - the Council passed Resolution 1973, authorizing states, under Chapter VII, to use "all necessary means" to protect civilians. The Council used the traditional language of civilian protection, "Expressing its determination to ensure the

is S/RFS/1894.

${ }^{89}$ UN Security Council, Report of the Secretary-General's Panel of Experts on Accountability in Sri Lanka, Mar. 31, 2011, 41.

"Ho Human Rights Watch, World Report 2010: Sri Lanka, Jan. 2010.

"UN Tells of "Bloodbath" in Sri Lanka, New York TrMes, May $11,2009$.

- U2 UN Security Council Presidential Statcment, S/PRST/2009/29, Oct. 28, 2009; UN Security Council Presidential Statement, S/PRST/2010/13, Fcb. 16, 2010.

33 UN Panel Calls for Court in Cuinea Massacre, Nkw York Times, Dec. 21, 2009.

${ }^{4} 4$ Barack Obama, Remarks by the President in Address to the Nation on Libya, Mar. 28, 2011.

45 UN Security Council Resolution 1970, S/RES/1970, Fcb. 26, 2011. Adopted unanimously. 
protection of civilians and civilian populated areas," but as in Resolution 1970, it also referenced the language of RtoP, "Reiterating the responsibility of the Libyan authorities to protect the Libyan population and reaffirming that parties to armed conflicts bear the primary responsibility to take all feasible steps to ensure the protection of civilians."

Resolution 1973 demanded "the immediate establishment of a cease-fire and a complete end to violence and all attacks against, and abuses of, civilians," and "authorize[d] Member States that have notified the Secretary-General, acting nationally or through regional organizations or arrangements, and acting in cooperation with the Secretary-General, to take all necessary measures, notwithstanding paragraph 9 of resolution 1970 (2011), to protect civilians and civilian populated areas under threat of attack in the Libyan Arab Jamahiriya, including Benghazi, while excluding a foreign occupation force of any form on any part of Libyan territory." 6 This last caveat was added to prevent a veto by those permanent members (Russia and China) with lingering concerns about the use of RtoP as an excuse for Iraq-style regime change.

To RtoP critics, that concern proved not to be wholly unfounded. The resolution's intent was to authorize NATO forces to implement a no-fly zone to prevent Libya from launching air attacks against civilian population centers. Perhaps inevitably, however, NATO's air campaign expanded well beyond its initial targets. Initial NATO strikes targeted Libyan air defenses, military planes, and command and control, but soon moved on to target Libyan armored units, military supply facilities, and the like. NATO's logic was straightforward: if the goal of Resolution 1973 was the protection of civilians, then these strikes were necessary, as Libyan forces did not rely on airpower alone to attack civilians. To NATO, the only way to ensure that the Libyan regime could not attack civilians was to essentially destroy the regime's military capabilities altogether, which had the predictable effect, in the end, of destroying the regime itself.

However logical, this interpretation of Resolution 1973 failed to satisfy NATO's critics. Russia and China both voiced strong criticisms, as did South Africa, and called for an independent investigation into whether NATO had exceeded its mandate under Resolution $1973 .{ }^{97}$ Russia declared that NATO had committed "numerous violations of international law" after an "arbitrary interpretation of Security Council resolution 1973 (2011)." 98

${ }_{96}^{6}$ UN Security Council Resolution 1973, S/RES/1973, Mar. 17, 2011. Adopted 10-0-5, with China, Russia, Brazil, Germany, and India abstaining.

97 Casey L. Coombs, Responsibility to Protect or Reform?, International Relations and Security Network (Apr. 12, 2012); Russia, NATO Clash over Libya Campaign, Modern Ghana, July 4, 2011; Russia Criticises France over Libya Arms Drop, AL Jazeera, June 3o, 2011.

$9^{8}$ UN Security Council Provisional Verbatim Record of the 6705th Meeting, S/PV.6705, Jan. 19, 2012. statement by Permanent Representative Vitaly Churkin (Russian Federation). 
As of this writing, March 2011 appears to have been the high water mark for RtoP in the Security Council. In late March, the Council again referenced RtoP, this time in the context of Côte d'lvoire, where post-electoral violence took the lives of at least 3,000 civilians. ${ }^{99}$ When President Laurent Gbagbo refused to step down after losing to rival Alassane Ouattara, the Council called on Gbagbo, in Resolution 1975, to respect the electoral results and cease attacks on civilians by forces under his control. The Council "express[ed] grave concern about the recent escalation of violence in Côte d'Ivoire and the risk of relapse into civil war" and "reaffirm[ed] the primary responsibility of each State to protect civilians." Acting under Chapter VII, Resolution 1975 authorized the UN peacekeeping force already in Côte d'Ivoire "to use all necessary means to carry out its mandate to protect civilians under imminent threat of physical violence." UN peacekeepers backed by French troops succeeded in preventing Gbagbo's forces from launching significant further attacks, and in April, Gbagbo was detained and ultimately transferred to the International Criminal Court.

In virtually every way, the Council's efforts in Côte d'Ivoire were an impressive success. As one journalist commented, "Within a week, former president Laurent Gbagbo, who had refused to accept defeat in an election and plunged his country into a steadily escalating spiral of violence and repression, was in custody, and within two weeks the majority of his forces had surrendered or rallied to the new President's side ... Côte d'Ivoire, stands as an instructive case study in international intervention, one which was swift, decisive and - most importantly - avoided what would surely have been a far-worse outcome."

Overshadowed by Libya, this RtoP success garnered few headlines. Perhaps more significantly, it ended quickly - well before the escalation of NATO's campaign in Libya led to the unraveling of the fragile understanding between the NATO powers and RtoP skeptics such as Russia and China. Since March 2011, the Council has continued to reference RtoP in resolutions on Sudan, Yemen, Libya, and Mali, ${ }^{101}$ but has not been willing to do so with regard to today's most glaring civilian protection crisis, the Syrian civil war. The Syrian conflict is estimated to have killed over 100,000 people, many of whom are civilians, ${ }^{102}$ but in large part because of Russian opposition, the Council has been unable to reach consensus on how to address it. Indeed, Russia and China have blocked or vetoed multiple Council resolutions on Syria. ${ }^{103}$ "We simply cannot accept a document under Chapter VII, one which would open the path

"' Human Rights Watch, "They Killed Them Like It Was Nothing"; The Need for Justice for Côte d'Ivoire's Post-Election Crimes, Oct. 2011, 4 .

${ }^{100}$ In Côte d'lvoire, a Model of Successful Intervention, ThE AtLAnTic, June 9, 2011, 1.

${ }^{101}$ Global Centre for the Responsibility to Protect, UN Security Council Resolutions Referencing RzP, available at http://www.globalrzp.org/resources/335.

${ }^{102}$ War Deaths in Syria Said to Top 10o,ooo, New York TIMks, June 26, 2013; Megan Price et al., Preliminary Statistical Analysis of Documentation of Killings in the Syrian Arab Republic, Benetech Human Rights Program (Jan. 2, 2013), 1.

${ }^{103}$ International Coalition for the Responsibility to Protect, Crisis in Syria, available at http://responsibi litytoprotect.org/index.php/crises/crisis-in-syria. 
for pressure of sanctions and ... to external military involvement in Syrian domestic affairs," Vitaly Churkin, Russian ambassador to the UN, told the Council. ${ }^{10+}$

\section{WHERE ARE WE NOW?}

This will not, of course, be the end of the story. As Gareth Evans, former Australian foreign minister and an author of the original ICISS report on RtoP observes, "I believe that - like most midlife crises - this one will prove survivable ... but I can't pretend that its full realisation will not be a work in progress for a long time to come."

"A work in progress" is an accurate summary of Security Council civilian protection work more generally. As noted in the introduction to this chapter, the Council has always concerned itself with civilian protection. True, that concern has been demonstrated only inconsistently, and there have been striking failures - but the general trend has been toward greater consistency and greater effectiveness.

This is particularly true when we consider that, despite the inevitable focus on coercive military interventions, many of the Council's civilian protection achievements have been smaller and more incremental, but not the less important for all that. As the decades have gone by, for instance, the Council has broadened the aperture in terms of what "counts" as a civilian protection issue. In its early decades the Council viewed civilian protection issues mainly as incidental to inter-state armed conflicts. As Hugh Breakey has noted, however, the Council has more recently shown a willingness to look at issues ranging from "mutilations in Sierra Leone, genocide in Rwanda, ethnic cleansing in the Balkans or disappearances in Latin America" and the particular vulnerabilities of displaced persons, refugees, women, ${ }^{106}$ and children ${ }^{107}$ during armed conflicts. ${ }^{108}$

\footnotetext{
${ }^{10}+$ Friction at the U.N. as Russia and China Veto Another Resolution on Syria Sanctions, Nkw York Truts, July 19, 2012.

${ }^{105}$ Yes, the UN Has a Duty to Intenene. But When, Where and How?, Tnt Guaruman, May +, 2013.

100) UN Security Council Resolution 1325, S/RES/1325, Oct. 31, 2000. Adopted unanimously.

${ }^{10-}$ Sec gencrally Clapter 1 of this book. As Genser and Stagno Ugarte note in Chapter 1, "In 2001, 'Childrea and Armed Conflict' broke new ground with Resolution 1379 (2001) on two fronts. The Comeil requested the Secretary-General to annex to his report 'a list of partics to armed conflict' that recruit or use children in violation of the applicable international law, enabling the Secretary-Gencral to cite state and non-state actors. Moreover, and more importantly, the Security Council cxplicitly acknow ledged the prerogative of the Secretary-General under Article 99 of the Charter to bring to the attention of the Conncil those situations which in his opinion may threaten the maintenance of international peace and security.'... Using its powers under Article 29 of the Charter, the Council has also cstablished a subsidiary working group enabling it to deepen its involvenent with some of these thematic agenda items: the Ad Hoc Working Group on Chitdren and Arned Conflict established by resolution 1612 (2005)." UN Security Council Resolution 1379, S/RFS/1379, Nov. 20, 2001; UN Sccurity Council Rcsolution 1612, S/RES/1612, July 26, 2005. Adopted unanimously.

ion Hugh Breakcy, "POC in Arned Conflict: Four Concepts" in Francis, Popovski, and Sanupford (eds.), Norys or Prothction.
} 
The Council has also greatly widened the range of civilian protection tools that it uses to address complex protection problems. These tools now include diplomatic pressure, monitoring, sanctions, ${ }^{109}$ the creation ${ }^{110}$ and use of accountability mechanisms, ${ }^{111}$ clearer civilian protection mandates, ${ }^{112}$ and an emphasis on improved civilian protection training for UN peacekeeping forces. ${ }^{113}$ As Breakey comments:

${ }^{109}$ The Council has imposed sanctions for, inter alia, perpetrating grave violations of international humanitarian law (see, e.g., UN Security Council Resolution 1572, S/RES/1572, Nov. 15, 2004, adopted unanimously; UN Security Council Resolution 1593, S/RES/1593, Mar. 31, 2005, adopted 11-0-4 with Algeria, Brazil, China, and the United States abstaining); complicity in attacks on civilians (S/RES/ 1970); targeting, killing, or maiming civilians in armed conflicts (see, e.g., UN Security Council Resolution 2002, S/RES/2002, July 29, 2011, adopted unanimously), the recruitment and use of child soldiers (see, e.g., UN Security Council Resolution 1698, S/RES/1698, July 31, 2006, adopted unanimously); and the sexual abuse of women in armed conflicts (see, e.g., S/RES/1572).

no The Council authorized the creation of a Special Court for Sierra Leone (with primacy over national courts) in Resolution 1315, S/RES/1315, for instance, and a Special Tribunal for Lebanon in Resolution 1757. See UN Security Council Resolutions 1315 and 1757, S/RES/1315 And S/RES/1757, Aug. 14, 2000 and May 30, 2007. Resolution 1315 was adopted unanimously, whereas Resolution 1757 was adopted 10-0-5, with China, Indonesia, Qatar, Russia, and South Africa abstaining.

in In Resolution 1564, the Council mandated the establishment of an International Commission of Inquiry on Darfur. After receiving its report, the Council referred the situation in Darfur to the ICC in UNSCR 1593 . UN Security Council Resolution 1564 , S/RES/1564, Sept. 16, 2004, adopted 14-0-4, with Algeria, China, Pakistan, and Russia abstaining; S/RES/1593. In 2011, the Council referred the situation in Libya to the ICC in Resolutions 1970 (2011) and 1973 (2011).S/RES/1970; S/RES/1973.

112 Consider, for instance, the United Nations Organization Mission in the Democratic Republic of the Congo (MONUC; renamed MONUSCO (United Nations Organization Stabilization Mission in the Congo) in 2010). As Anthony Gambino notes in Chapter 14 of this book, "[a]s of early 2013, MONUSCO, with a budget of $\$ 1.4$ billion per year, has approximately 23,000 personnel, including more than 19,000 military and police. It operates under a strong, peace enforcement mandate from the Security Council focused on protection of civilians, stabilization, and peace consolidation ... A series of strengthening resolutions finally culminated in the adoption of UN Security Council Resolution 1565, adopted on October 1, 2004, in which the Council gave MONUC a full Chapter VII mandate to, among many assignments, deploy throughout the Congo to protect Congolese civilians and UN personnel "us(ing) all necessary means." (See UN Security Council Resolution 1565, S/RES/1565, Oct. 1, 2004, adopted unanimously.) In December 2009, relates Gambino, "the UN Security Council added even stronger language to MONUC's mandate emphasizing the primacy of civilian protection in the resolution which presently governs MONUC's activities in the Congo. It stated, 'MONUC... shall have the following mandate, in order of priority: (a) Ensure the effective protection of civilians ... (The Security Council) (e)mphasizes that the protection of civilians ... must be given priority in decisions about the use of available capacity and resources, over any ... other tasks ....' UN Security Council Resolution 1906, S/RES/1906, Dec. 23, 2009. Adopted unanimously. As Gambino discusses, this mandate has not, unfortunately, translated into a discernible reduction in violence against civilians; he analyzes the reasons for this in Chapter 14.

${ }^{13} \mathrm{Sec}, \mathrm{c.g} ., \mathrm{S} / \mathrm{RES} / 1894$. Resolution 1894 focuses squarely on peacekeeping civilian protection capabilities, noting, for instance, the need to "upgrade the strategic oversight of peacekeeping operations mindful of the important role peacekeeping operations play for the protection of civilians and reaffirms its support to the efforts made by the Secretary-General to review peacekeeping operations and to provide enhanced planning and support capabilities," as well as the need for "clear, credible and achievable mandates, based on accurate and reliable information on the situation on the ground, and a realistic assessment of threats against civilians and missions" and "comprehensive operational guidance ... mission-wide planning, pre-deployment training, and senior leadership training on the protection of civilians." 
The Security Council ... has a wide arsenal of actions at its disposal to respond to large-scale violence against civilians ... [It can] call for parties to observe international humanitarian law ... promote accountability for violations by setting up ad hoc courts or referring situations to the International Criminal Court. Security Council POC responses may also include sanctions, arms embargoes, separation of civilians and combatants, ensuring access for humanitarian aid, establishing safe zones, monitoring and reporting, protection of refugees and counteracting hate media ... Since 1999, UNSC mandates for peace operations evince a marked progression towards giving POC an increasingly central role, and in authorizing coercive force under Chapter VII of the Charter....

Further, Council willingness to act is not limited to reaction. The UNSC explicitly highlights the significance of preventive measures that may be undertaken by the United Nations, including dispute resolution, preventive military and civilian deployment, and avenues for fact-finding ... [And] the strategic toolkit at the disposal of the UNSC continues to expand. In his last two reports Ban Ki-moon lists strategies including coordination with protective humanitarian actors, involvement with the civilian population's self-protective strategies, facilitating engagement with non-state actors, potential constraints on arms trading, improvements in and expansions of reporting, fact-finding and commissions of enquiry, protection within refugee and IDP camps and the safe return, including to appropriate property/and entitlements, of refugees and IDPs.

It is difficult to find appropriated metrics for evaluating the success of Security Council civilian protection efforts. There is no control group, and although the Council's failures are glaring, its successes are often less visible. By definition, Council actions that prevent harm to civilians - or stop harmful activities from continuing for as long as they otherwise might - have a "dog that didn't bark in the night" quality. How does one measure the gap between what happened and what could have happened?

Although somewhat unsatisfying, it is perhaps most accurate to conclude by noting that although international civilian protection norms, institutions, and practices remain uneven, they have been slowly maturing. George $\mathrm{H}$. W. Bush's "new world order" never fully materialized, but the post-Cold War period has nonetheless been characterized by an increased willingness, on the part of the Security Council, to focus on the nitty-gritty aspects of successful civilian protection. We have seen a slow but relatively steady growth in the development of effective UN institutions and coordination mechanisms for civilian protection, including the development of civilian protection doctrine and training for UN peacekeeping forces.

Little of the credit for this can be claimed by the Security Council itself, unfortunately. For the most part, as Genser and Stagno Ugarte argue, the Council has "not been in the lead" when it comes to human-rights-related issues in general, but has rather been "reacting and responding to pressure from outside." ${ }^{\prime 14}$ To use a

${ }^{114}$ Chapter 1. 
metaphor from American football - and one often applied to the US Supreme Court - the Council is bad at tackling, but moderately good at piling on. It responds to pressure from NGOs and the media when that pressure becomes impossible to ignore, but without external pressure, it rarely opts for decided action for civilian protection purposes. And as we have seen, even when external pressure is extreme, action is not always forthcoming; at times, the same divisions that have plagued the Council since its birth continue to paralyze it. The Security Council was born out of the greatest civilian protection crisis the world has ever known, but today, we remain far from the original vision of "the peoples of the United Nations ... to save succeeding generations from the scourge of war." 115

That this is so is unsurprising. The Security Council is not an institution made up of autonomous actors, but rather an institution made up of member states. More specifically, Council discussions generally involve diplomats one or two tiers down from the top of their national hierarchies. Each of these diplomats must abide by his or her instructions, and these instructions reflect the domestic political calculations of national leaders far more than they reflect any cosmopolitan commitment to the global good. We speak of the Council as an entity with a personality and will of its own, but this is of course a fiction; the Council can never be more than the sum of the states that make it up, and given its voting rules, the whole is often rather less than the sum of the parts. Ultimately, improving Security Council civilian-protection efforts will depend more on the evolution of norms and practices external to the Council, and on Security Council reform efforts, than on anything internal to the Council.

"United Nations, Charter of the United Nations, 1 U.N.T.S. XVI, entered into force Oct. 24, 1945 , preamble. 